\title{
CHARACTERISTICS AND PREVENTION OF SPORTS INJURIES IN TAEKWONDO TRAINING
}

\author{
CARACTERÍSTICAS E PREVENÇÃO DE LESÕES ESPORTIVAS NO TREINAMENTO DE TAEKWONDO \\ CARACTERÍSTICAS Y PREVENCIÓN DE LESIONES DEPORTIVAS EN EL ENTRENAMIENTO DE TAE KWON DO
}

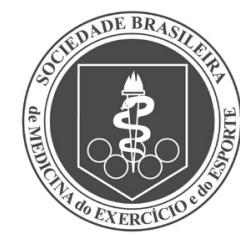

Original Article ARTIGO ORIGINAL Artículo Original
Shupeng Xiao' (D)

(Physical Education Professional)

1. Jiangxi University of Finance and Economics, School of Physical Education (Mailu Campus),

Nanchang, Jiangxi, China.

\section{Correspondence:}

Shupeng Xiao

Nanchang, Jiangxi, China. 330013. DoDo12131@163.com

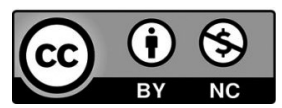

\begin{abstract}
Introduction: With the extensive and in-depth development of Taekwondo in China, more and more people participate in Taekwondo training. Due to the lack of experience of some coaches and the misunderstanding of scientific sports training by young athletes, injuries occur from time to time. This has a bad effect on Taekwondo itself, and it can also damage the health of athletes. Objective: This article discusses joint injuries in Taekwondo and analyzes the characteristics of Taekwondo sports injuries and preventive methods. Methods: This article uses a questionnaire applied to young athletes to gain an understanding of the sports injuries situation. Results: The most common injury sites were feet and joints. The nature of the injuries is mostly soft tissue injury, ligament laceration, and muscle strain. The most serious injuries are kidney and perineal damage. Conclusion: Improving the level of training, strengthening medical supervision, and paying attention to the timely treatment of acute injuries are important ways to reduce the occurrence of trauma. Level of evidence II; Therapeutic studies - investigation of treatment results.
\end{abstract}

Keywords: Adolescent; Tae Kwon Do; Ankle joint; Athletic injury.

\section{RESUMO}

Introdução: Com o desenvolvimento extenso e profundo do Taekwondo na China, cada vez mais pessoas participam do treinamento nesseesporte. Com a falta de experiência de alguns treinadores e a compreensão errônea de jovens atletas quanto ao treinamento esportivo científico, de vez em quando ocorrem lesões. Isso tem efeito negativo sobre o próprio Taekwondo e também pode prejudicar a saúde dos atletas. Objetivo: Este artigo discute lesões articulares no Taekwondo e analisa as características das lesões do esporte, bem como os métodos de prevenção. Métodos: Este artigo aplicou um questionário a jovens atletas para obter uma compreensão da situação das lesões esportivas. Resultados: Os locais de lesão mais comuns foram pés e articulações. A natureza das lesões éprincipalmente nos tecidos moles, laceração de ligamento e tensão muscular. As lesões mais graves são danos renais e perineais. Conclusões: Melhorar onivel de treinamento, fortalecer a supervisão médica e prestar atenção ao tratamento oportuno de lesões agudas são maneiras importantes de reduzir a ocorrência de traumas. Nível de Evidência ll; Estudos terapêuticos - Investigação dos resultados do tratamento.

Descritores: Adolescente; Tae Kwon Do; Articulação do tornozelo; Traumatismos em atletas.

\section{RESUMEN}

Introducción: Con el amplio y profundo desarrollo del Tae Kwon Do en China, cada vez más personas participan en el entrenamiento de este deporte. Debido a la falta de experiencia de algunos entrenadores y a la comprensión errónea dejóvenes atletas sobre el entrenamiento deportivo científico, ocasionalmente se producen lesiones. Esto tiene un efecto negativo en el propio Tae Kwon Do y también puede perjudicar la salud de los atletas. Objetivo: Este artículo trata de las lesiones articulares en el Tae Kwon Do y analiza las características de las lesiones en este deporte, así como los métodos de prevención. Métodos: En este artículo se aplicó un cuestionario a jóvenes atletas para conocer la situación de las lesiones deportivas. Resultados: Los lugares más comunes de las lesiones fueron los pies y las articulaciones. La naturaleza de las lesiones es principalmente en los tejidos blandos, rotura de ligamentos y tensión muscular. Las lesiones más graves son los daños renales y perineales. Conclusiones: Mejorar el nivel de entrenamiento, reforzar la supervisión médica y prestar atención al tratamiento oportuno de las lesiones agudas son formas importantes de reducir la incidencia de traumatismos. Nivel de Evidencia ll; Estudios terapéuticos - Investigación de los resultados del tratamiento.

Descriptores: Adolescente; Tae Kwon Do; Articulación del tobillo; Traumatismos en atletas.

\section{INTRODUCTION}

Taekwondo is a competitive sport that originated in Korea with fierce confrontation and superb skills. It is widely spread around the world. It was listed as an official event in the Sydney Olympic Games after being listed as an official event in the 10th Asian Games in 1986. Although the
Taekwondo movement in China has not started for a long time, it has also improved a lot in recent times. In particular, the level of women's Taekwondo has been at the forefront of the world. Due to Taekwondo's confrontation and fierce characteristics, the incidence of injuries is higher. ${ }^{1}$ How to reduce damage, especially the occurrence of major damage, is 
a question worth considering. Improving the scientific nature of sports training to improve the performance of athletes and prolong sports life has also become one of the issues that have received much attention from coaches and athletes. The author investigated the ankle joint injuries of young Taekwondo athletes in our school. At the same time, we have an in-depth understanding of the incidence of young Taekwondo athletes' ankle injuries, the causes and characteristics of the injuries, discover the injuries'laws, and look for countermeasures. Improve the scientificity and pertinence of coaches'training work through the survey results. Only in this way can young athletes strengthen their awareness of protecting against sports injuries to prolong sports life and improve sports performance.

\section{METHOD}

\section{Research object}

There are 42 Taekwondo athletes from Provincial Sports School, including 31 male athletes and 11 female athletes. The age range is 12.5 17.6 years old, the average is $(15.2 \pm 2.8)$ years old, the average height is $(169.3 \pm 6.8) \mathrm{cm}$, and the average weight is $(56 \pm 4.3) \mathrm{kg}$. Athletes participate in Taekwondo training for 1 to 6 years, and the average training is $(2.9 \pm 1.4)$ years. The athletes come from 10 first-level athletes, 6 second-level athletes, and 26 unrated athletes.

\section{Survey method design}

The questionnaire's content includes the general situation of the athletes, the location of the ankle joint injury, the time of injury, and the reason. A total of 42 questionnaires were distributed in June 2020, and 42 were recovered. The recovery rate was 100\%, of which 41 were valid questionnaires, and the effective rate was $98.0 \%$.

\section{Damage identification method based on time series model} Damage recognition mechanism

This section uses the ankle joint of an athlete with three degrees of freedom. The ankle joints of the system vibrate freely in the horizontal direction. $k, c$ represents the stiffness coefficient and damping coefficient of the athlete's ankle joint, respectively. $m_{1}, m_{2}, m_{3}$ represents the amount of ankle joint exercise. ${ }^{2}$ The acceleration time history data of the ankle joint are denoted by $\ddot{x}_{1}, \ddot{x}_{2}, \ddot{x}_{3}$ respectively. The time series model of ankle joint 2 can be established by taking $\ddot{x}_{1}, \ddot{x}_{3}$ as the model input and $\ddot{x}_{2}$ as the model output. The model expression is shown in equation (1).

$$
\begin{aligned}
& \ddot{x}_{2}(t)+a_{1} \ddot{x}_{2}(t-\Delta t)+a_{2} \ddot{x}_{2}(t-2 \Delta t)= \\
& b_{11} \ddot{x}_{1}(t)+b_{12} \ddot{x}_{1}(t-\Delta t)+b_{13} \ddot{x}_{1}(t-2 \Delta t)+ \\
& b_{21} \ddot{x}_{3}(t)+b_{22} \ddot{x}_{3}(t-\Delta t)+b_{23} \ddot{x}_{3}(t-2 \Delta t)+e(t)
\end{aligned}
$$

The coefficients in formula (1) include the physical and mechanical parameters $\left(k_{1}, k_{2}, c_{1}, c_{2}, m_{1}, m_{2}\right)$ of the structure. When the system is damaged, the acceleration response of ankle joint 2 will no longer satisfy equation (1). At this time, the output $\ddot{x}_{2}$ data sequence obtained by substituting the measured $\ddot{x}_{1}, \ddot{x}_{3}$ as input into equation (1) after the system is damaged will be different from the measured $\ddot{x}_{2}$ data sequence. According to the degree of difference between the two, we can identify and evaluate the damage state of the system.

\section{Damage characteristic factors}

Suppose the program is listed as $Y_{i}$ when the actual acceleration of a certain node is measured, and the average value is $\bar{Y}$. The acceleration time program predicted by the time series model is listed as $y_{i}$. According to the difference between the two sequences, the degree of fit $\xi$ is defined as

$$
\xi=\frac{1}{100 \times\left(Z^{1 / p}\right)+1}
$$

$p$ is the calculation order; $Z$ is expressed as formula (3):

$$
Z=\frac{\sum_{i=1}^{n}\left(\left|y_{i}-Y_{i}\right|^{p}\right)}{\sum_{i=1}^{n}\left(\left|Y_{i}-\bar{Y}\right|^{p}\right)}
$$

$n$ is the sample size. According to the definition, the interval of the degree of fit $\xi$ is $(0,1)$. The greater the degree of fit, the closer the structure to be identified is to the undamaged structure. Without damage, $y i$ will be exactly equal to $Y$. When the structure is damaged, the model's coefficients in formula (1) also change accordingly. ${ }^{3}$ Acceleration time history data is predicted by a time series model calculated without damage. We will have a deviation from the measured acceleration time-history data. Therefore, the value of the damage factor (damagefactor, DF) can be defined as 1 - $\xi$ according to the degree of fit.

\section{Statistical methods}

We use SPSS10.0 to build the database. The article takes the average of the general situation of the athletes. The cause, time, and calculation rate of injury caused by ankle joint injury were analyzed by $x 2$ test.

\section{RESULTS}

\section{Ankle injury}

Through the investigation of the ankle joint injuries of young Taekwondo athletes in provincial sports schools, it was found that 32 of the 42 athletes surveyed had a history of ankle joint injuries. ${ }^{4}$ The incidence rate was $76.1 \%$. See Table 1 and Table 2 for details.

\section{Causes of the ankle injury}

Inattention, inadequate preparation activities, and irregular technical movements are the main factors that cause injury. However, there was no statistically significant difference in the incidence rate ( $P>0.485)$. Physical fatigue factors accounted for $28.1 \%$ of the factors of youth Taekwondo injury. The incidence is also relatively high (Table 3 ).

Table 1. Ankle injuries of young Taekwondo athletes.

\begin{tabular}{c|c|c}
\hline Project & Person times & Proportion (\%) \\
\hline Lateral ligament & 13 & 40.6 \\
\hline Medial ligament & 10 & 31.3 \\
\hline $\begin{array}{c}\text { Lateral ligament + inferior tibiofibular } \\
\text { syndesmosis ligament }\end{array}$ & 5 & 15.6 \\
\hline $\begin{array}{c}\text { Medial ligament + syndesmotic } \\
\text { tibiofibular ligament }\end{array}$ & 4 & 12.5 \\
\hline Total & 32 & 100 \\
\hline
\end{tabular}

Table 2. Time of ankle injury of young Taekwondo athletes.

\begin{tabular}{c|c|c}
\hline Project & Person times & Proportion (\%) \\
\hline Morning exercises & 3 & 9.4 \\
\hline Training & 15 & 46.9 \\
\hline In the game & 9 & 28.1 \\
\hline In non-Taekwondo events & 3 & 9.4 \\
\hline Other & 2 & 6.3 \\
\hline Total & 32 & 100 \\
\hline
\end{tabular}

Table 3. Causes of ankle joint injuries of young Taekwondo athletes.

\begin{tabular}{c|c|c}
\hline Project & Person times & Proportion (\%) \\
\hline Inattention & 18 & 56.3 \\
\hline Inadequate preparation & 16 & 50 \\
\hline Irregular technical actions & 14 & 43.8 \\
\hline Physical fatigue & 9 & 28.1 \\
\hline Other & 2 & 6.3 \\
\hline
\end{tabular}




\section{DISCUSSION}

Through the investigation of taekwondo athletes' ankle joint injuries, it was found that the injury rate was $76.1 \%$. Because there are certain differences in age composition, training time, sports years, and sports performances of our study subjects, there are also differences in the incidence of ankle joint injuries. ${ }^{5}$ This investigation found that the incidence of ankle joint injuries among young Taekwondo athletes is higher, and the severity will affect their sports training.

More than 90\% of taekwondo attacks are based on kicks. For example, forward swing kick, half-moon kick, etc. This requires the ankle joint to be completed during plantar flexion. At this time, the bony structure of the ankle joint is at the most unstable stage, and sports injuries are prone to occur. The loose ligaments around the ankle joint before the foot is weight-bearing facilitates the adjustment of the bones of the ankle joint. After the foot is loaded, it can stabilize the ankle joint. ${ }^{6}$ The anatomical shape and structure of the ligaments around the ankle joint and the close interaction with the articular surface ensure the guidance and stability of their movements. Of course, the integrity of the articular surface of the ankle joint is the basis for the close contact between articular cartilage. And its stability depends on the integrity of the ligaments around the joints. The survey showed that the lateral collateral ligament injury occurred most frequently, accounting for 40.6\%. The medial ligament injury accounted for 31.3\%. However, the syndesmotic ligament did not have a single injury related to its strong and elastic structure and low mobility. Some scholars believe that by increasing the exercises for the ankle joint range of motion, the ankle joint can withstand greater load during confrontation activities to avoid the occurrence of ankle joint injuries. ${ }^{7}$ Coaches should consider the athlete's gender, age, characteristics, health status, and athletic level when formulating an individualized training plan for young Taekwondo athletes. At the same time, it is also necessary to focus on strengthening the leg muscles and the ligaments around the ankle joint, especially the exercise of the lateral and medial ligaments.

From the time of ankle injury, it can be seen that nearly half of the injuries occur in daily training. In this survey, the incidence of injuries among teenagers in the game accounted for $28.1 \%$. Analysis of the reasons is that young athletes have little training and competition experience and are prone to deformation of technical movements and poor posture. This increases the occurrence of damage. In addition, 15.6\% (morning exercises and others) of young athletes suffered ankle injuries during non-training competition time. This is related to the younger, active, and poor self-control of the athletes. In addition to paying attention to athletes' training, coaches should also pay more attention to them in their daily lives to avoid injuries. ${ }^{8}$ This is very different from adult Taekwondo athletes, and coaches should pay attention to them in daily life and training. At the same time, coaches also need to strengthen their education on preventing sports injuries and train their anti-interference ability.

The main reason for ankle injuries is inattention. This is slightly different from other investigations on the causes of injuries of Taekwondo athletes. The second reason for the injury is that the preparation activities before the training competition are not adequately caused. Once again, the athletes have irregular technical movements in the confrontation. Irregular technical movements in training or competition can easily cause acute or chronic injuries. ${ }^{9}$ This has a lot to do with the short training time of young athletes and their inadequate mastery of movements. Both training and competition require full concentration, and the relaxation of thought is the prelude to injury. Warm-up activities can raise the body temperature, increase muscle metabolism, and increase blood supply and the stretchability of ligaments. This helps prevent sports injuries. Therefore, coaches need to strengthen athletes' awareness that "you can't train without a warm-up" and urge that warm-ups are not just a formality and go through the field so that athletes can form good habits. And there is guidance for each athlete's characteristics and injury history to conduct targeted preparation activities.

\section{CONCLUSION}

Coaches must train young Taekwondo athletes scientifically, and popularizing medical knowledge related to Taekwondo can effectively improve athletes' awareness of self-protection against sports injuries. In this way, it can reduce sports injuries and further improve its comprehensive ability of self-management and self-training. This will prevent athletes from ending their sports careers prematurely due to sports injuries.

The author declare no potential conflict of interest related to this article

AUTHORS' CONTRIBUTIONS: The author made significant contributions to this manuscript. Shupeng Xiao: writing and data analysis ; article review and revising the article

\section{REFERENCES}

1. Kim JC, Park KJ. Convergence Analysis of the between Bone Mineral Density, Cardiorespiratory Functional Capacity and sports injury of youth Taekwondo Athletes. Korea Convergence Society. 2020;11(10):125-31.

2. Ryu S. Injury Prevention Strategies of Landing Motion of Jumping Front Kick to Apply Free Style Poomsae of Taekwondo. JSB. 2020;30(1):37-49.

3. ParkWY. Effects of plyometric training on Sargent jump, posture control and lower extremity injury criterion in Taekwondo demonstrator. J Korean Appl Sci Technol. 2021;38(3):851-9.

4. Lystad RP, Alevras A, Rudy I, Soligard T, Engebretsen L. Injury incidence, severity and profile in Olympic combat sports: a comparative analysis of 7712 athlete exposures from three consecutive Olympic Games. Br J Sports Med. 2021;55(19):1077-83.

5. Seo BD, Kim HJ, Ju JY. Effect of Muscle Fatigue on the Proprioception by the Taekwondo Training
Type. Korean Soc Phys Med. 2020;15(3):1-9.

6. Jabbar MAJ, Chandran J, Yuan OY, Masilaman R. Prevalence of Musculoskeletal Injuries Among Taekwondo Players In Malaysia. MJPHM. 2021;21(2):382-93.

7. Zarei M, Johari K, Bagherian R. Lower Extremity Risk Factors in Iranian Adolescent Taekwondo Players. PTJ. 2020;10(1):7-14.

8. Zheng R, Zhou J, Zhang T. Biomechanical Risk Assessment of Non-Contact Anterior Cruciate Ligament Injury in Taekwondo Athletes. J Adv Med. 2020;3(3):1-5.

9. Rüther J, Willauschus M, Hammer A, Schröder J, Bail HJ, Geßlein M. Analyse von Muskelverletzungen und „Return-to-Training "im Elite-Taekwondo-Ergebnisse einer prospektiven Kohortenstudie über einen Zeitraum von 5 Jahren. Sportverletz. 2021;35(01):52-7. 